4-12-2008

\title{
Popular Sovereignty And Legality
}

Christopher J. Peters

University of Baltimore School of Law, cpeters@ubalt.edu

Follow this and additional works at: http://scholarworks.law.ubalt.edu/all_fac

Part of the Law Commons

\section{Recommended Citation}

Christopher J. Peters, Popular Sovereignty And Legality, (2008).

Available at: http://scholarworks.law.ubalt.edu/all_fac/878

This Article is brought to you for free and open access by the Faculty Scholarship at ScholarWorks@University of Baltimore School of Law. It has been accepted for inclusion in All Faculty Scholarship by an authorized administrator of ScholarWorks@University of Baltimore School of Law. For more information, please contact snolan@ubalt.edu. 


\section{WAYNE STATE \\ UNIVERSITY \\ LAW SCHOOL}

POPULAR SOVEREIGNTY AND LEGALITY

Christopher J. Peters

Wayne State University Law School Legal Studies Research Paper Series

No. 08-14

April 12, 2008

Papers posted in the The Wayne State University Law School Legal Studies Research

Paper Series can be downloaded at the following url:

http://WWW. ssrn. com/link/Wayne-State-U-LEG . html

and

The Social Science Research Network Electronic Paper Collection:

http://ssrn.com/abstract=1120330 


\title{
Popular Sovereignty and Legality
}

\author{
Christopher J. Peters
}

\begin{abstract}
This talk, prepared for delivery at the 2008 Wayne State University Humanities Center Faculty Fellows Conference, explores the relationship between popular sovereignty and legality. Legality - in particular, legal rights entrenched in a constitution - often is thought to conflict with popular sovereignty in a way that mirrors the supposed tension between individual autonomy and legal authority. Both perceived conflicts, however, rest in part upon the problematic idea that the law knows better than legal subjects what to do in particular cases. In fact, legal authority is best justified as a means of resolving disputes about what to do in particular cases. A dispute-resolution account of law shifts the focus away from the supposed conflict between law on the one hand and individual autonomy or popular sovereignty on the other, and toward the function of law as a means of settling conflict about, among other things, what autonomy and popular sovereignty entail. In particular, the dispute-resolution account suggests that judicially enforced constitutional rights might serve as a relatively neutral means of settling disagreements about the relationship between political majorities and political minorities.
\end{abstract}




\title{
Popular Sovereignty AND Legality ${ }^{*}$
}

\author{
C.J. Peters ${ }^{\dagger}$
}

I.

Is the idea of popular sovereignty somehow inconsistent with the idea of legality? You wouldn’t think so from American political rhetoric, in which "democracy" and "the rule of law" typically are packaged together and labeled for export to less fortunate parts of the globe. ${ }^{1}$ And yet it seems that, when push comes to shove, either popular sovereignty or legality must give way to the other.

Imagine that the large majority of the people of a democratic nation, in the wake of a devastating terrorist attack, decides it is wise to imprison suspected terrorists indefinitely and without judicial process. But suppose the nation has a written constitution whose norms purport to be immune from change through ordinary democratic politics; and suppose one or more of those constitutional norms purport to prohibit the action the people now want to take. Why should the people risk further catastrophe by obeying what now seem to be unwise constitutional provisions? Of course, the people could amend their constitution according to the procedures required by the constitution itself, but why should the people be put to this trouble in order to do

* (c) 2008 Christopher J. Peters. All rights reserved. This is the text of a talk prepared for the Wayne State University Humanities Center's Faculty Fellows Conference on the topic “Sovereignty, Justice and the Law Across Disciplines,” held on April 11, 2008. The ideas expressed here form part of an ongoing book-length project in which I present a dispute-resolution model of law and democracy. Please do not cite or quote this text without the author's express permission.

${ }^{\dagger}$ Associate Professor of Law, Wayne State University Law School. For their helpful comments, I thank the participants in a faculty workshop at the Law School, and especially Derek Bambauer, Tony Dillof, and Paul Dubinsky. Thanks also to Bob Sedler for organizing the workshop and to Walter Edwards and the WSU Humanities Center for sponsoring the Conference and providing financial support.

${ }^{1}$ President George W. Bush, for example, frequently cited "the rule of law" as one of the values that would accompany the global spread of “democracy." See, e.g., George W. Bush, Remarks to the U.S. Chamber of Commerce, Washington, D.C. (Nov. 6, 2003) ("Recent surveys in Arab nations reveal broad support for political pluralism, the rule of law, and free speech. These are the stirrings of Middle Eastern democracy ....”); George W. Bush, Speech at Brasilia, Brazil (Nov. 6, 2005) ("Each democracy has its own character and culture that reflects its unique traditions and history. Yet all free and successful countries share some common characteristics: freedom to worship, freedom of the press, freedom of speech, economic liberty, equal justice under the rule of law, equal citizenship for all - and the limitation of state power through checks and balances.”) (emphases added). 
what they now think is right? Amending a constitution requires considerable time and resources, both of which might more usefully be devoted elsewhere during a crisis. And it might seem foolish to rewrite the constitution in order to deal with what appears to be a momentary emergency that is likely to pass in relatively short order.

If we believe the nation's constitution poses at least some normative obstacle to the people's doing what they now think is wise, then we have recognized a tension between popular sovereignty, at least in its purest form, and legality or "the rule of law," at least in its constitutional form. This tension seems analogous to the supposed conflict between individual moral autonomy and legal authority. According to the anarchist philosopher Robert Paul Wolff, moral autonomy requires each individual to take an action only if she herself believes it is appropriate on its merits. ${ }^{2}$ On this view, legal authority is inconsistent with autonomy because it purports to require a person to act, not because she herself thinks that action is appropriate, but because someone else - the wielder of legal authority - thinks so.

Suppose, for example, that a motorcyclist carefully considers all the pros and cons of wearing a helmet and decides it is best not to wear one. If the law tells her she must wear a helmet, the law seems to be trumping her own normative judgment and thus denying her ability to act autonomously. The relationship of the law to the individual's autonomy looks like a microcosmic version of the relationship between constitutional law and popular sovereignty. In either context, the law claims to override the best judgment of its subject (individual person or collective "people”) about how to act.

Of course, it seems true that both individuals and peoples must accept obedience to "law" of some form in order to function as individuals or peoples. The Kantian understanding of autonomy involves not complete freedom from constraint, but the ability to bind oneself to

\footnotetext{
${ }^{2}$ See Robert Paul WolfF, In Defense of AnARchism (1970).
} 
norms that are the product of one's own will; ${ }^{3}$ and indeed the literal translation of the Greek word “autonomy” is "self-law-giving.” Some degree of self-law-giving seems necessary for any person to live her life as she wishes - to be free from harmful impulsive or compulsive behaviors, for instance, and to make and follow through on plans.

It likewise seems impossible for a democratic people to exist and operate as a people without following some laws it has established for itself. At the very least, a people will have to establish basic ground rules for defining who they are - who belongs to "the people" and who does not - and for determining by what means and in what forms they can be said to act collectively. They will, that is, have to constitute themselves and their institutions and processes of government; they will need "constitutional” law in the core sense of that concept. So, for example, in the United States Constitution "We the People of the United States" purport both to bind and, in a sense, to establish themselves; to determine their identity by prohibiting the use of certain criteria (such as race and gender) to deny citizenship; to prescribe institutions and procedures for making, enforcing, and interpreting their laws; and so forth. Without some foundational legal norms like these, a people would be not a collectivity but simply a collection of individuals, and popular sovereignty (or indeed sovereignty of any kind) would be impossible.

But to recognize the need for some amount of self-law-giving, as an individual or as a people, is not to acknowledge the legitimacy of laws imposed by some external force. In the constitutional context, we might be able to imagine that "the people" that constituted itself and its institutions however long ago is one and the same "people” that is defined, enabled, and constrained by that constitutional act today. Indeed we may have to indulge this conceptual stretch in order to make the ideas of a "people” and of popular sovereignty coherent. This conception of constitutional law as merely, and necessarily, constitutive of self-government

\footnotetext{
${ }^{3}$ See Immanuel Kant, Groundwork of the Metaphysic of Morals 98-99 (H.J. Paton ed., 1964).
} 
seems inapt, however, when constitutional norms leave the realm of the merely institutional or procedural and enter the realm of the substantive - when a constitutional provision purports, not to enable popular self-governance, but to limit what the self-governing people is entitled to do. Such constraints appear less like the people’s self-made plans and more like an external force substituting its judgment for the people’s own.

This kind of constraint seems to be the chief function of many or most of those legal norms we classify as “constitutional rights.” Consider the Fifth Amendment’s requirements of grand-jury indictment and due process of law, or the Sixth Amendment's guarantees of the assistance of counsel and a speedy and public trial by jury. None of these rights comfortably can be understood as constituting Americans as a people or as providing the necessary institutional and procedural framework for our exercise of popular sovereignty. Each of them, rather, purports to limit our ability to exercise our sovereignty by, for example, detaining suspected terrorists indefinitely without charge when we think that is the right thing to do. Constitutional rights seem irreconcilably to conflict with popular sovereignty, and thus they beg for some justification.

II.

I want to suggest here that each of these perceived tensions - between autonomy and legal authority generally, and between popular sovereignty and constitutional rights in particular - is infected by an inadequate account of the authority of law.

Consider two different ways of justifying the authority of the law. One of them goes back at least to Plato and counts among its adherents Aristotle, Rousseau, John Stuart Mill, and most contemporary legal positivists, including Joseph Raz, who is its most influential current proponent. I'll refer to this justification as the epistemic-guidance account of legal authority. 
According to the epistemic-guidance account, law derives its legitimate authority from its capacity to identify the best course of action in most cases, a capacity that exceeds that of the person (or the people, collectively) that is subject to the law. ${ }^{4}$ On this account, the motorcyclist should obey the helmet law, despite her disagreement with it, because the law is more likely than the motorcyclist herself to know whether wearing a helmet is the right thing to do. On this account, too, the American people should obey the commands of the Fifth and Sixth Amendments, despite disagreeing with their requirements for treating suspected terrorists, because the Constitution is more likely than the people themselves to know whether indictment, trial by jury, access to counsel, and due process of law are the right things to do in those circumstances.

If the epistemic-guidance account is correct, then there really is a conflict between individual moral autonomy and legal authority, and between popular sovereignty and constitutional rights: In each context, the external judgment embodied in the law trumps the judgment of the legal subject (the individual person or the collective people), and the legal subject is no longer fully self-governing.

But there is good reason to question the epistemic-guidance account. ${ }^{5}$ It is, first of all, quite implausible to think that the law’s capacity to identify the right course of action is superior to the legal subject's in every case. As Aristotle observed, general laws often - one might say invariably - apply suboptimally in some particular cases covered by them. ${ }^{6}$ For Aristotle, this was a function of that fact that a lawmaker could not foresee every circumstance in which its

\footnotetext{
${ }^{4}$ For Raz's version of this account, which he calls the “service” conception, see JosEPH RAZ, THE MORALITY OF FREEDOM 23-105 (1986).

${ }^{5}$ For a sophisticated critique of the epistemic-guidance account along these lines, see Scott J. Shapiro, Authority, in The OXFord HANDBOOK OF JuRisprudenCE \& Philosophy OF LAW 382 (Jules Coleman \& Scott Shapiro eds., 2002). Shapiro refers to what I call the epistemic-guidance account as the "mediation model,” because it holds that law mediates between legal subjects and the reasons applicable to their actions.

${ }^{6}$ See Aristotle, Nicomachean Ethics, bk. V, ch. 10, at 1020 (W.D. Ross trans., Richard McKeon ed. 1941).
} 
general law would apply. (The eighteenth-century Framers of the Fifth and Sixth Amendments, for instance, hardly could have anticipated international terrorism and weapons of mass destruction.) But it seems likely that even with respect to many cases the lawmaker can anticipate, its judgment about what to do in those cases will be less reliable than the on-the-spot judgment of the legal subject actually faced with them. Why should we think a state legislature is a better judge than the individual motorcyclist about whether, as to her, the costs of going helmetless outweigh the benefits? Why should we imagine that the balance between individual liberty and national security struck by eighteenth-century Framers is somehow better than the balance we could strike for ourselves today?

Of course, the likelihood that the legal subject will be a better judge of what to do than the law in some cases isn’t necessarily fatal to the epistemic-guidance account; it still might be the case that the law is the best judge more often than not. But the law's generally superior epistemic capacity does not provide a reason to obey the law in one of those exceptional cases where the premise does not hold; and the problem is that any given case might be one of those exceptional cases. Indeed, the best evidence we are likely to have regarding whether the case we find ourselves in is such a case is the existence, and strength, of our own disagreement with what the law is telling us to do. If the motorcyclist strongly believes the mandatory-helmet law is wrong as applied to her, this belief is powerful evidence that the law does not know better than she does in that case - and thus that the law’s purported authority over her in that case is illegitimate. If the American people strongly believe that indefinite detention of suspected terrorists is the right thing to do, that belief itself is an argument that the Fifth and Sixth Amendments have no authority over us on that question. 
The trouble with the epistemic-guidance account, then, is that the claim it makes for the legitimacy of legal authority is weakest when the need for legal authority is strongest - namely in those cases where legal subjects vigorously disagree with the substance of the law's commands. There is, however, an alternative account of legal authority that can avoid this difficulty, an account I will call the dispute-resolution model.

The pedigree of the dispute-resolution model, while not as long as that of the epistemicguidance account, still reaches back pretty far, through Kant and Locke to probably its first great champion, Thomas Hobbes. On the dispute-resolution account, law draws its authority not from its supposedly superior capacity to determine the right course of action in particular cases, but rather from its capacity to resolve disputes among legal subjects about what is the right course of action in particular cases. A person should obey a disagreeable law, not because the law is more likely to be correct than she is in that particular case, but because the costs of obedience are less than the dispute-related costs that would exist absent the law. So our motorcyclist has reason to obey the helmet law despite her strong disagreement with it, namely that the law represents a reasonable resolution of social disagreement about the wearing of motorcycle helmets, and that the costs of continuing that disagreement without resolution ultimately are greater than the costs of accepting a resolution she finds distasteful. Likewise, the American people have reason to honor the limitations imposed by the Fifth and Sixth Amendments - not because those Amendments necessarily "get it right” on the subject of detaining suspected terrorists, but because they represent a reasonable settlement of social disagreement regarding what it means to "get it right” on that issue.

Note that the dispute-resolution account can avoid the self-erosion problem that plagues its rival. The dispute-resolution account makes no claim that law generates “correct” answers in 
all, most, or even many cases, and so it is not embarrassed by the existence of cases in which the law seems to be wrong. More to the point, a legal subject's disagreement with the law's command in a given case does not constitute evidence against the law's legitimate authority over her in that case. The motorcyclist can’t deny the law's authority on the ground that she disagrees with what the law is telling her to do; the existence of disagreement about what to do is precisely the point of having authoritative law.

Note also - and here we get to the heart of the matter - that the dispute-resolution account takes the sting out of the supposed conflict between legal authority and individual moral autonomy. A small part of the point here is the fact that threats to individual autonomy can come from other individuals, and that law (and the means to enforce it) can reduce these threats. Hence the bare Hobbesian justification of law, as a way to coerce self-interested bad actors into refraining from themselves coercing others. ${ }^{7}$ But the simple Hobbesian story is only a small part of the point, because by itself it won't satisfy Wolff and other defenders of autonomy. Wolff resents, not law's coercion of those who act in bad faith to impair others' autonomy, but law’s substitution of its commands for the good-faith judgments of individuals. He objects, not to laws against stealing other people’s motorcycles, but to laws requiring helmet use by motorcyclists whose best judgment does not require it.

As envisioned by Wolff, then, the law-autonomy conflict embodies a stark choice between the individual's and the law’s moral judgments. The dispute-resolution account challenges this vision by recognizing that a more fundamental choice needs to be made: a choice among the conflicting moral judgments of different individuals. The fact is that people often disagree about the boundaries between one person's autonomy and another's, or about what constitutes "autonomy” in the first place and whether it is worth protecting, or about countless

\footnotetext{
${ }^{7}$ See Thomas HobBes, Leviathan (C.B. Macpherson ed., 1968) (1651).
} 
other questions of morality and policy. People disagree, for instance, about whether helmet use is a matter for the individual motorcyclist to decide, or instead is something that the public - in the interests of family members, employers, other motorists, those who pay insurance premiums, and so forth - ought to be in the business of regulating. These sorts of disagreements might be motivated primarily by conflicting self-interests, as Hobbes emphasized, but they need not be. As Jeremy Waldron explains in his excellent book Law and Disagreement, many disagreements will be the product of good-faith, reasonable views that, thanks to something akin to what John Rawls called "the burdens of judgment," happen to conflict with each other. ${ }^{8}$ Perhaps most disagreements will derive from some inextricable combination of self-interest and reasonable, good-faith views.

What the dispute-resolution account allows us to see is that the ubiquitous fact of disagreement, whatever its source, renders inadequate a simplistic dichotomy between legal commands and individual moral judgment. Individuals' moral judgments often conflict, and when they do someone's judgment necessarily must be compromised or overridden. Proponents and opponents of mandatory-motorcycle-helmet laws can't both have their way. Nor can they dispute the issue indefinitely, with all the direct and opportunity costs, and the ongoing uncertainty, that would entail. The issue must be settled somehow; and it might be that the law, if it is generated and enforced in the proper way, is capable of reaching a settlement that everyone (even the losers) should accept. If so, then it is not open for one of those losers to object that the law impairs her autonomy by overriding her own moral judgment. Overriding the judgments of some in order to resolve conflicts among competing judgments is the reason for having law.

\footnotetext{
${ }^{8}$ See JEREMY WALDRON, LAW AND DisAGREEMENT 111-13, 151-53 (1999) (citing JOHN RAWLS, POLITICAL LIBERALISM 54-58 (1993)).
} 
We might extend this insight to the case of popular sovereignty. The tendency of many writers on the relationship between popular sovereignty (or democracy) and constitutional rights - superficially a rhetorical tendency but often, I think, one that reflects more substantively engrained ways of thinking - is to refer to "the people” as a monolithic entity that stands in a dialectic relationship to some external, nonpopulist force, such as the constitutional Framers or the Supreme Court. ${ }^{9}$ This tendency, not coincidentally, runs backward to the Framers themselves; Hamilton famously defended judicial review in the $78^{\text {th }}$ Federalist as a means of ensuring that "the power of the people is superior to both" the judicial and the legislative power. $^{10}$ But of course "the people" of the United States in 2008 never agree among themselves on anything, any more than they did in 1787 (and probably, in fact, somewhat less). The crucial question of modern democratic theory is not whether the will or judgment of "the people” may or should be constrained by some external norms like constitutional rights, but rather how to adjudicate inevitable disagreements among the people about, among other things, whether “rights" should be recognized and, if so, which ones and to what extent.

It may be that constitutional law is, or can be, a reasonable response to this problem of disagreement among the people about issues of rights, in the same way that law more generally can be a reasonable response to disagreement among individuals about their own respective

\footnotetext{
${ }^{9}$ Here are just a couple of prominent examples: AlEXANDER M. BICKEL, THE LEAST DANGEROUS Branch: The Supreme Court AT The BAR of Politics 16-17 (2d ed. 1986) (1962) (“[W]hen the Supreme Court declares unconstitutional a legislative act or the action of an elected representative, it thwarts the will of the representatives of the people of the here and now ....”); LARRY D. KRAMER, THE PEOPLE THEMSELVES: POPULAR CONSTITUTIONALISM AND JUDICIAL REVIEW 7 ("We in the twenty-first century tend to divide the world into two distinct domains: a domain of politics and a domain of law. In politics, the people rule. But not in law. Law is set aside for a trained elite of judges and lawyers whose professional task is to implement the formal decisions produced in and by politics.”). Defenders of judicially enforced constitutional rights often fall into this rhetorical pattern themselves (with Alexander Hamilton as an historical role model; see note 10 and accompanying text); e.g., CHRistopher L. EISGRUBER, CONSTITUTIONAL SELF-GOVERnMENT 3 (“ ... I maintain that the Supreme Court should be understood as a kind of representative institution well-shaped to speak on behalf of the people about questions of moral and political principle.”). (1788).

${ }^{10}$ Alexander Hamilton, Federalist No. 78, in ThE FEDERALIST PAPERS 436, 439 (Isaac Kramnick ed., 1987)
} 
rights and duties. But there is a powerful objection to such a conclusion, posed most articulately in some of Professor Waldron's recent work.

\section{III.}

If I read him right, Professor Waldron agrees with the basic Hobbesian insight that law is primarily a product, not of some urge to tell people how to act, but of the imperative to resolve disputes among people about how to act. But Professor Waldron notes that law can serve that function only to the extent it provides a reason for the "losers" of disputes nonetheless to accept the results that law prescribes. The crucial question for Professor Waldron then becomes: What kind or kinds of reasons for acceptance can law offer to the losers of disputes? ${ }^{11}$

Professor Waldron suggests that the reasons for acceptance must be noninstrumental ones; they must derive from some intrinsic aspects of the procedure employed to resolve disputes, such as its fairness or its participatory nature. ${ }^{12}$ He points out that the rightness or goodness of a particular result generated by a procedure cannot serve as a reason for the loser to accept that result, because of course the loser will not agree that the result is right or good; that's why the procedure is needed in the first place. ${ }^{13}$ We can't tell the motorcyclist to obey the helmet law because wearing a helmet is the right thing to do, which is precisely the assertion she disagrees with. And if the substantive quality of the result won't satisfy the loser, the only thing left seems to be something inherent in the procedure itself: perhaps the fact that the loser has had the opportunity to participate in that procedure on equal terms with the winner.

\footnotetext{
${ }^{11}$ See WALDRON, supra note 8, at 243-49; Jeremy Waldron, The Core of the Case Against Judicial Review, 113 YALE L.J. 1346, 1369-72 (2006).

${ }^{12}$ To be precise, Waldron argues that what he sees as the core procedural value - the right of participation is best understood as noninstrumental. See WALDRON, supra note 8, at 239-54. Elsewhere, Waldron acknowledges the possibility of a certain kind of instrumentalist or "outcome-based" justification of procedure, namely one that turns on that procedure's capacity to produce accurate results on a systemic level. See Waldron, supra note 11, at 1373-74.

${ }^{13}$ See Waldron, supra note 11 , at 1373.
} 
From this premise - that the law must provide noninstrumental procedural reasons to accept its commands - Professor Waldron builds a case against judicially enforced constitutional rights. ${ }^{14}$ He notes that majoritarian democracy is about as fair and evenhandedly participatory a procedure as one could devise for the resolution of disputes: Each affected party gets a single vote and thus an equal say in the outcome. In contrast, judicial enforcement of constitutional rights gives vastly disproportionate decisionmaking power to a small elite: unelected judges, and of course the constitutional Framers, who can’t even be counted among the affected parties, having been dead for one or two centuries. Majoritarian democracy thus offers to the losers a strong reason for acceptance - their fair participation in the process - that constitutional adjudication utterly lacks.

We should take note, however - and with all due respect to Professor Waldron - that the procedural feature of fair participation he identifies with majoritarian democracy is not necessarily the only process-based reason one might have for accepting an otherwise disagreeable result. Consider a feature we typically identify not with popular sovereignty but with legality: the presence of a neutral third party to arbitrate a dispute. To be sure, fair participation is important in legal proceedings as well, as the Supreme Court has recognized by interpreting due process to require notice and an opportunity to be heard. ${ }^{15}$ But notice and an opportunity to be heard in court become meaningless if the presiding judge is biased against one of the parties or strongly predisposed against one of their legal positions. In adjudication, the reasonable neutrality of the decisionmaker is a process-based reason to accept the decision; the absence of that neutrality is a process-based reason to reject it.

\footnotetext{
${ }^{14}$ See WALDRON, supra note 8, at 211-312; Waldron, supra note 11, at 1386-95.

15 See, e.g., Mullane v. Central Hanover Bank \& Trust Co., 339 U.S. 306 (1950); Fuentes v. Shevin, 407 U.S. 67 (1972).
} 
Could it be that the concept of judicial neutrality has an analogue in the idea of judicially enforceable constitutional rights? Consider two salient features of those rights that distinguish them from the results of majoritarian democracy. ${ }^{16}$ First, constitutional rights are determined, not by argument from first principles of morality or about political costs and benefits, but through the interpretation of textual provisions ratified by the supermajoritarian act of a previous generation. In deciding whether indefinite detention of suspected terrorists violates the Fifth Amendment, the question is not whether that detention is morally right or wrong or good or bad policy; the question is whether it accords with whatever the Amendment means by "due process of law.”

Second, the primary task of interpreting the Constitution is assigned to lawyers - experts in the interpretation of normative texts - who operate at a considerable remove from the everyday pressures of partisan politics. The meaning of "due process of law" as it applies to the detention of suspected terrorists will be spelled out, not by moral philosophers or welfare economists or bureaucrats, and certainly not by public-opinion pollsters, but by judges who are neither appointed nor subject to removal by popular election.

If constitutional adjudication were designed to serve the same function as majoritarian democracy, these procedural properties of interpretation and political insulation would seem entirely mysterious. But they begin to make some sense if we understand constitutional law as a response to disputes about majoritarian democracy. In the American system, adjudication of constitutional rights decides two kinds of questions: those involving claims that certain activities or interests (such as self-expression, religious belief and practice, sexual and reproductive choice, and racial equality) are immune from calculations of majority interest or preference; and

\footnotetext{
${ }^{16}$ To their disadvantage, Professor Waldron believes. See WALDRON, supra note 8, at 220, 289-92; Waldron, supra note 11 , at 1376-86.
} 
those involving the basic terms of membership and fair participation in the political community. These questions tend to be perennially and deeply divisive. And the political losers on these issues - those who claim some immunity from the results of majoritarian politics or an unfair denial of full participation in those politics - tend, by the very nature of the issues, to distrust majoritarian politics as a way of resolving them.

Constitutional adjudication offers some degree of distance from the politics whose results or structure are being challenged. When a court assesses the constitutionality of a statute, it doesn't simply choose sides between the current political majority and the current political minority, as majoritarian politics does virtually by definition. Instead, it tries to resolve the majority-minority dispute by drawing to some meaningful extent on the supermajoritarian judgments made by previous generations at pivotal moments in the nation's history; this is the value of the otherwise mysterious interpretive focus of constitutional law. The very "otherness" of the Framers who drafted and ratified the Constitution is what gives their commands some claim to neutrality with respect to our current disputes. And the relative political insulation of the judges who must interpret their commands reinforces that claim to neutrality. Thus the message a court tries to send to the losers of constitutional disputes is not "you have been outvoted” or even “you are wrong” - messages implicit in the results of majoritarian politics but rather "your position on this issue does not accord with our best understanding of what the Constitution - the law - requires.” It is a version of the same message that judges, at least good ones, always try send to losing litigants in any kind of case.

Of course there are many qualifications and complexities here. For one thing, the views of the Framers about particular contemporary issues almost never are identifiable and often do not exist at all, despite what some originalists would have us think. This puts much or most of 
the task of judgment squarely in the hands of contemporary judges, who rarely if ever are "neutral” in the sense of lacking even an ideological stake in the controversy being decided. (Not to pick on Justice Scalia, but anyone who thinks he is morally "neutral” on, say, questions of religious freedom or remedies for racial inequality has not been paying attention.)

But the practical question we have to ask - the only question we can ask, I think - is whether a system of constitutional adjudication, taken as a whole, can offer enough detachment from majoritarian politics to be acceptable as a way of resolving, if only provisionally (always only provisionally), those controversies about majority-minority relations that are too persistent and deep-seated to be trusted, by the minority, to majoritarian politics alone. The answer will not invariably be “yes”; but I think it has been “yes” most of the time in the American system. Usually - and admittedly with important lapses, as in Dred Scott, Lochner v. New York, Bush v. Gore, arguably Roe v. Wade - the constitutional basis of the Supreme Court's decisions has been persuasive enough that the Court has avoided accusations, at least from the mainstream, of simply taking sides.

And of course constitutional neutrality or the appearance of it, especially when it obviously is so severely compromised in practice, might sometimes have to yield to that other procedural value that Professor Waldron rightly identifies as important, the value of fair participation. But we should notice in this regard that American constitutional adjudication actually strikes something of a balance between the two values. Its interpretive focus, the relative political insularity of its judges, and the longevity of a typical Justice's tenure on the Court keep it from shifting with every momentary change in the political winds. At the same time, the political inputs into constitutional adjudication are many and diverse. Individual Justices may remain on the Court for long periods of time, but the Court's overall membership in 
fact changes quite frequently; and when it does, the appointments process is intensely political. Judges, moreover, are not magically immune from the social, cultural, and political trends that move the society to which they belong. And the adjudicative process itself is, at the constitutional level, broadly and actively participatory; the Supreme Court rarely decides a constitutional question without hearing from well-financed litigants and amici curiae on all sides. The result is that constitutional jurisprudence, assessed over the medium- to long term, rarely strays too far from the election returns.

If this is right, then in a sense popular sovereignty - not as a mythical unanimous will of “the people,” but as a basic premise that all contentious issues must eventually be settled democratically - ultimately trumps legality after all; even in a constitutional democracy, the people ultimately make the law that binds them. The principle of legality simply reminds us that democracy is characterized by disagreement, and it suggests that democratic procedures by themselves will not always be capable of resolving those disagreements in a way the losing minority can accept. 